IRA-International Journal of Education \& Multidisciplinary Studies

ISSN 2455-2526; Vol.03, Issue 03 (2016)

Institute of Research Advances

http://research-advances.org/index.php/IJEMS

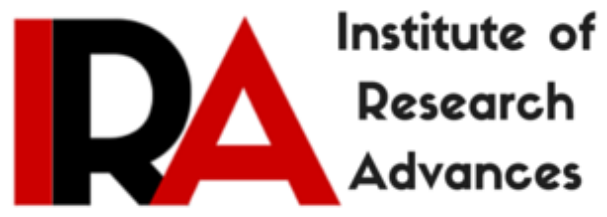

\title{
The Dilemma of the TVET Teacher in Developing Countries in the 21st Century
}

\author{
Makworo Edwin Obwoge, \\ KISII University, \\ P.O Box 408 - 40200, KISII, Kenya.
}

DOI: http://dx.doi.org/10.21013/jems.v3.n3.p7

\section{How to cite this paper:}

Edwin Obwoge, M. (2016). The Dilemma of the TVET Teacher in Developing Countries in the 21 st Century. IRA International Journal of Education and Multidisciplinary Studies (ISSN 2455-2526), 3(3).

doi:http://dx.doi.org/10.21013/jems.v3.n3.p7

(C) Institute of Research Advances

\section{(cc) EY-NC}

This works is licensed under a Creative Commons Attribution-Non Commercial 4.0 International License subject to proper citation to the publication source of the work.

Disclaimer: The scholarly papers as reviewed and published by the Institute of Research Advances (IRA) are the views and opinions of their respective authors and are not the views or opinions of the IRA. The IRA disclaims of any harm or loss caused due to the published content to any party. 


\begin{abstract}
Technology is a very dynamic commodity and keeping up with the ever changing trends in various technologies is an issue of great concern for many technologists in the $21^{\text {st }}$ century. Technology changes every 18 months and hence the practitioners need to keep up with the pace in order to remain relevant. The Technical and Vocational Education and Training (TVET) sector is often most affected since it trains technologists for the industrial sector in most developed and developing economies. The TVET instructor always finds himself in a dilemma since skills get obsolete quickly yet he has to continue delivering content in area of specialty. As the industrial sectors demands change, so should the skills of the TVET instructor change to match the ever changing trends of the industry. In most developing countries, there are no set out mechanisms of re-skilling the TVET instructor to keep him updated with the latest technologies in the private sector. This paper reviews literature on the dilemma of the TVET instructor in the $21^{\text {st }}$ century and make recommendations for implementation in developing countries.
\end{abstract}

Key Words: Technical and Vocational Education Training, Relevance, Skills

\title{
INTRODUCTION
}

Technology is a very dynamic commodity and in the fast progressing world, one has to keep up or keep chasing the eminent changes that must take place. Current technologies are fast progressing from analog to digital which is more efficient and intelligent in nature. Due to this there has arisen a technological divide not only between regions in the world and developing countries versus developed countries but also there is a divide between person to person. This is because of the generation differences in our society today and also differing technology adoption levels. The young generation has come into the global arena when there is a lot of dynamics in technological changes ranging from communication technologies, computer technologies and even mobile smart devices. There is a lot of curiosity in the young generation whereas the older generation is slow and often uninterested.

Technological advancements have had a great impact on the physical environment and even in social interaction hence affecting current societal values and cultures. The education sector is one of the most affected systems with the new rising trends in technology. In the past, educators used to carry out research and pass on the findings to the industry to execute the processing of proven results and then disseminate this to the community in terms of products or services. Today's educators are in dilemma. In today scenario, the manufacturing sector has employed researches and scientists who carry our research and come up with new innovations. The education systems have ended up being recipients instead of creators of knowledge. The knowledge acquired by trainees is currently not always relevant to the dynamic technological workplace. The TVET teacher of today has to learn before going to teach because he has obsolete skills.

\section{CHALLENGES FACED BY THE $21^{\text {ST }}$ CENTURY TVET INSTRUCTOR}

The technology instructor has found himself in a dilemma in this $21^{\text {st }}$ century. This is because the technologies used in training the instructors while in technical teacher training schools have become obsolete and are rarely currently used in industry. The skills harbored by the instructors have hence become obsolete and re-skilling is necessary. A further dilemma is that students they train who are a younger generation 
have more exposure and access to current technologies which most instructors know nothing about.

The classroom has become a source of new information passing on from the trainee to the instructor. Instructors find themselves unable to tackle learner queries and hence find themselves in a very disturbing scenario. The technologies and techniques of teaching and learning have also diversified due to the advent of computers, computer networks and mobile devices. Most developed countries have turned to competence based education where learners are able to learn state of the art skills. The competency-based education (CBE) approach allows students to advance based on their ability to master a skill or competency at their own pace regardless of environment. This method is tailored to meet different learning abilities and can lead to more efficient student outcomes. There is also low societal perception of TVET instructors which has led to poor attitudes towards manual work.

According to Axmann et. al. (2015), the youth employment crisis and evident skills mismatch between labour market needs and general and vocational education has raised recognition of the importance of technical and vocational education and training (TVET). The capacity of TVET systems to provide high quality and relevant training depends largely on the quality of its teachers and trainers, and, by extension, on the quality of their teacher training systems.

According to Axmann et. al. (2015), TVET teacher training programmes have the following challenges;

- Lack of structure and relevance to ensure that TVET is recognized as a potential career path and that teachers and trainers are adequately prepared to share these skills with young people;

- Lack of responsiveness and inclusion to ensure that TVET teacher training programmes are not limiting the specific fields and opportunities available to instructors and the students they teach;

- Lack of innovation and progress to ensure that TVET teacher training programmes are constantly evolving and adapting to the latest advances in pedagogy and technology; and

- Lack of representation and communication to ensure that TVET teachers and trainers have an active voice and collegial support system to encourage them and enhance job satisfaction.

TVET teacher training programme in developing countries have not been well articulated and many assume that the skills can be acquired without training. Pre- and in-service programmes for teachers and instructors are often not in place. This greatly hinders the teacher from undertaking lifelong learning. Vocational curricula, which are still frequently prepared and set by government officials with little or no exposure to the world of work, represent another weak point in the learning chain. Even worse, previously adopted curricula are extended by incorporating new content without scrapping outdated, irrelevant material (Axmann, 2004). Teaching and training materials are often outdated and not relevant to what is needed for specific skills development (Johanson and van Adams, 2004). All this pose a lot of challenge to the progress of the TVET instructor.

TVET instructors also face the challenge of changing instructional technologies that have come up like online learning, distance learning and also the new assessment 
strategies. The traditional paper exams are quickly being overtaken by competency assignments and other class presentations and even group work.

\section{CONCLUSION}

Skills and knowledge are the engines of economic growth and social development of any nation (Goel, 2010), and Technical Vocational Education and Training (TVET) holds the key to training the skilled and entrepreneurial workforce needed for the changing technological workforce (Afeti, 2010). The TVET instructor therefore needs to be well equipped with all it takes to prepare a trainee for the world of work. With the challenges facing the TVET instructor discussed above, developing countries need to seriously consider ways that can be employed to ensure that they remain relevant and lifelong learning becomes an integral part of their survival. If this is not observed, then the graduates of TVET institutions in developing countries will not fit into the global market.

\section{RECOMMENDATIONS}

Based on the foregoing review and discussions, the following recommendations will serve to inform policy and all involved stakeholders in handling TVET instructor issues in the face of the dynamic world of technology.

1. The developing countries governments through their TVET sectors should introduce TVET teacher skills upgrade programmes in order to re-skill the Instructors with relevant skills necessary for training and the world of work. This programmes should include new teaching technologies and strategies, new assessment models and time in the industry from time to time.

2. Legal policies linking the industrial or manufacturing sector with TVET institutions should be well articulated and put in place.

3. A nation centre for industry and technical institutions collaboration should be set up and charged with the responsibility of carrying out research on new technologies and also be at the fore front in ensuring timely curriculum reviews to reflect the true situation in the workplace.

4. TVET instructors should change their attitudes towards new technologies and be ready to be retrained and embrace new skills as need arises from time to time.

5. The developing country governments should ensure that TVET teacher training institutions are responsive to the dynamic world of technology and should always be equipped with state of the art training facilities and equipment to ensure that the trainers come out fully qualified to handle the current generation of trainees

\section{REFERENCES}

Afeti, G. (2010). Technical and vocational education and training for industrialization. $\quad$ Retrieved April 9, 2016, from http://www.arrforum.org/publications/documents/Afeti\%20Technical\%20Education.p df

Axmann, M. (2004). "Facilitating Labour Market Entry for Youth through Enterprise-based Schemes in Vocational Education and Training and Skills Development". SEED Working Paper No. 48: Geneva, ILO. 
Axmann, M., Byusa, M., La Rue, J., Nordstrum, L. \& Rhoades, A. (2015). Vocational teachers and trainers in a changing world: the imperative of high-quality teacher training systems. Employment Policy Department Employment working Paper No.177: Geneva, ILO.

Goel, V. P. (2010). Technical and vocational education and training (TVET) system in India for sustainable development. Retrieved April 7, 2016, from http://www.unevoc.unesco.org/up/India_Country_Paper.pdf

Johanson, R. \& Adams, A. (2004). Skills development in Sub-Saharan Africa (Washington D.C., World Bank). 